\title{
Economic Comparison of Honey Mesquite Control Methods with Special Reference to the Texas Rolling Plains
}

\author{
R.E. WHITSON AND C.J. SCIFRES
}

\begin{abstract}
Although economic responses to honey mesquite control varied considerably within and among resource regions in Texas, aerial applications of herbicides generally produced higher annual rates of return on the investment than did mechanical alternatives. Statewide, aerial applications of $2,4,5-\mathrm{T}$ produced the greatest annual rates of return, averaging $15.7 \%$ for deep range sites and $11.0 \%$ for shallow range sites for projected livestock responses when cattle prices were estimated to a verage $\$ 0.97 / \mathrm{kg}(\$ 44.00 / \mathrm{cwt}$, 1978 dollars). Statewide, annual rates of return from aerial application of herbicides for honey mesquite control on shallow sites (statewide) varied from $-8.3 \%$ to $18.1 \%$, based on the $\$ 0.97 / \mathbf{k g}$ livestock price. When cattle prices were varied from $\$ 0.82 / \mathbf{k g}$ $(\$ 37.00 / \mathrm{cwt})$ to $\$ 1.05 / \mathrm{kg}(\$ 47.50 / \mathrm{cwt})$, annual rates of return from aerial application of 2,4,5-T to deep sites on the Rolling Plains and Rolling Red Plains of Texas ranged from 9.6\% to 17.9\%. Chaining of honey mesquite on deep sites of the Rolling Plains and Rolling Red Plains produced rates of return from $7.1 \%$ to $12.5 \%$. While the economic feasibility of herbicides in general was determined to be greater than that from the use of mechanical practices, rates of return from herbicides are more price sensitive than mechanical treatments. Over the 20-year planning period, tame pastures in the Rolling Plains produced the greastest accumulated net present value $(\$ / h a)$ when the annual interest rate charged to the added investment was $5 \%$ or less. When the annual interest rate was $7 \%$ or 9\%, the net present values of herbicide treatments exceeded those of the mechanical methods.
\end{abstract}

The Texas range livestock industry faces perennial economic problems because of unstable markets, inevitable drought, increasing taxes, livestock losses from predators and poisonous plants, and rising production costs. Economic pressures have forced many ranch firms to increase breeding herd numbers and reduce fixed costs to increase profit potential. However, most ranchers have limited means for increasing land holdings by purchase or lease because of the limited availability of lands and the relatively low

\footnotetext{
The a uthors are associate professor, Departments of Range Science and Agricultural Economics; and professor, Department of Range Science, Texas A\&M University, College Station, Texas 77843

The efforts of Julia Scifres in manuscript typing and preparation are highly appreciated. The authors are grateful to Rhett Johnson and D. B. Polk, Sr., Soil Conservation Service, Temple, Texas, for their work in data collection.

Approved by the Director, Texas Agr. Exp. Sta. as TA-15666.

Manuscript received January $10,1980$.
}

cash flow potential of rangelands. Consequently, many producers "become larger" by increasing the herd size on their existing land area in response to short-term economic pressurcs. Unfortunately, cow herds have often been expanded beyond the long-term forage production potential of the land.

Continual heavy grazing, periodic drought, and the absence of the influence of fire (which once suppressed brush invading Texas grassland) have reduccd annual forage production on most native rangeland, compared to its ecological potential (Scifres 1980) Approximately 28 million ha of Texas rangeland are infested with one or more brush species, and honey mesquite (Prosopis glandulosa Torr. var. glandulosa) infests about 22 million ha of these rangelands (Smith and Rechenthin 1964). It has been estimated that 16 million ha of Texas rangeland require brush control to improve forage production (U.S.D.A., Cons. Needs Inv. 1970).

Considerable research has emphasized improved honey mesquite control methods (Bovey and Meyer 1974; Fisher et al. 1970; Scifres 1973; Scifres et al. 1977; Wiedemann et al. 1977) but there is relatively little published information concerning the economic efficiency of these methods. Some workers have evaluated treatment costs (Boykin 1960; Wiedemann and Cross 1975) but did not consider benefits of brush control because of the lack of production response data amenable to economic analysis. As Dahl et al. (1978) indicated, some of the past research on livestock production responses to honey mesquite control resulted in conservative livestock response estimates because stocking rates were not adjusted following treatment. For example, Robison et al. (1970) reported an average $9 \% /$ ha increase $(20.3 \mathrm{~kg} / \mathrm{ha}$ to $22.1 \mathrm{~kg} / \mathrm{ha})$ in weaned calf production on the Rolling Plains if stocking rates were not adjusted following aerial spraying with 2,4,5-T [2,4trichlorophenoxy)acetic acid]. Robison et al. (1970) reviewed research indicating that weaning weights were increased by about $15 \mathrm{~kg} /$ calf, and that steer gains were increased by about $14 \mathrm{~kg}$ (summer grazing) following honey mesquite control (Fisher et al. 1959; Robison et al. 1969). In a subsequent study, Cross and Fisher (1975) reported an average weaning weight increase of about 11.3 $\mathrm{kg} /$ calf as well as an increased stocking rate from $1 \mathrm{AU} / 11.1$ ha to 1 $\mathrm{AU} / 9.8$ ha which jointly increased production by $19 \% /$ ha. Moreover, based on conversion of forage standing crop to carrying capacity of steers and averaged across differing site conditions, Dahl et al. (1978) reported a predicted increase in beef production ( $\mathrm{kg} / \mathrm{ha}$ ) of nearly $30 \%$ following aerial spraying on the Rolling 
Plains. Although these results are restricted to relatively few production situations, they indicate the importance of increasing carrying capacity as well as individual animal performance as indicators of economic effectiveness of honey mesquite control alternatives.

Although previous studies generally report favorable economic benefits associated with brush control in Texas (Brown et al. 1974, Osborne and Witkowski 1974, Sharp and Boykin 1967, Whitson et al. 1975, Whitson et al. 1977, Workman et al. 1965), they cannot be used to assess fully statewide economic feasibility of honey mesquite control because of variation in methodology, economic decision criteria, time period of the study, or because they were based on an evaluation of a single control alternative at one location. Variation in degree of infestation, rainfall, soils, livestock production practices, and management objectives results in an extremely large number of potential production situations.

Reliable economic comparisons are needed by governmental agencies responsible for establishing policy and technical assistance, by range managers concerned with decisions at the firm level, and by research organizations for use in determining research priorities. Impacts of eliminating or limiting use of a particular practice cannot be assessed accurately unless all other feasible control alternatives are included in the analysis, and the economic trade-offs among the control alternatives are identified. Ranch managers need results of comparative economic studies to improve firm-level decisions regarding the feasibility of honey mesquite control and the most profitable method for their situation. Research planning should incorporate economic implications of potential practices to efficiently allocate available resources for development of brush management technology.

The principal objective of this study was to develop cconomic comparisons at the ranch firm level of some of the more commonly used honey mesquite control practices in Texas. Statewide economic comparisons and more specific detailed comparisons from the Rolling Plains and the Rolling Red Plains are reported.

\section{Procedures and Rationale}

Range scientists employed by the Soil Conservation Service completed questionnaires requiring "best estimates" of livestock production responses to more common honey mesquite control alternatives for the major land resource areas. These data were developed into projected 20-year livestock carrying capacity response curves for specific honey mesquite control situations. Economic analysis of specific honey mesquite control alternatives as related to general range site production potential (deep or shallow), level of pretreatment honey mesquite canopy cover (dense $=>21 \%$ and moderate $=10-20 \%$ ), and rainfall patterns within a given resource region are reported by Whitson and Scifres (1979). Estimates were based on representative cow-calf operations within each of the 14 major land resource areas of the state (Fig. 1).

For this study, a capital budgeting present value analysis (Whitson et al. 1979) was conducted for selected honey mesquite control alternatives to allow calculation of an internal rate of return and a 20-year accumulated present value for selected discount rates of $0 \%, 5 \%, 7 \%$, and $9 \% .^{1}$ Projected rates of return from across the state were compared based on four commonly used practices selected to represent a range in cost/return relationships often utilized by ranch mangers in each resource region. While the honey mesquite control situations in this study represent a significant part of each region, they do not necessarily represent an "average" response over the total resource region.

Honey mesquite control alternatives evaluated were aerial applications of 2,4,5-T or dicamba (3,6-dichloro-o-anisic acid), root

The principal advantage of a present value analysis is that it allows proper economic consideration of the timeliness of cash flows as a cost of brush control. A positive accumulated net present value means the actual annual rate of return on the investment was greater than the interest rate selected for use in the present value analysis. An internal rate of return represents the maximum annual interest rate an individual could pay on all added capital required for a specific project and breakeven by the end of the planning period.

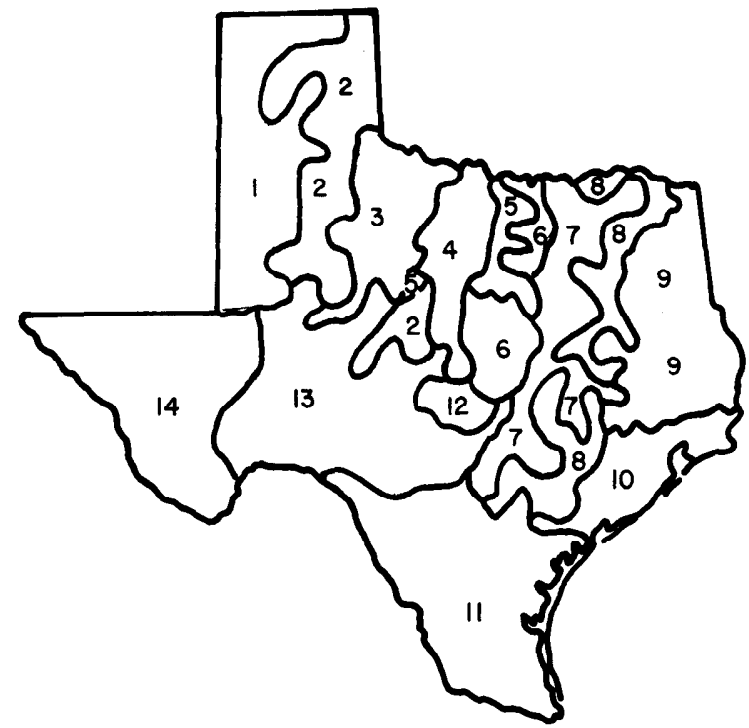

1. HIGH PLAINS

2. ROLLING PLAINS

3. ROLLING RED PLAINS

4. NORTH CENTRAL PRAIRIES

5. CROSS TIMBERS

6. GRAND PRAIRIES

7. BLACKLAND PRAIRIES
8. TEXAS CLAYPAN

9. EAST TEXAS TIMBERLAND

10. COASTAL PRAIRIES

II. RIO GRANDE PLAINS

12. CENTRAL BASIN

13. EDWARDS PLATEAU

14. TRANS PECOS
Fig. 1. Major land resource areas of Texas.

plowing and seeding an adapted native grass mixture, and the establishment of tame pasture. ${ }^{2}$ Cost of aerial application of 2,4,5$\mathrm{T}$ varied from $\$ 13.58 /$ ha to $\$ 15.22 /$ ha/treatment depending on rate of herbicide applied. Cost of other alternatives were $\$ 18.53 /$ ha to $\$ 21.87 /$ ha for dicamba application; $\$ 88.98 /$ ha to $\$ 284.17 /$ ha for root plowing and seeding; and $\$ 172.97 /$ ha to $\$ 295.36 /$ ha for tame pasture establishment. Initial costs/ha averaged $\$ 14.02, \$ 19.40$, $\$ 147.06$ and $\$ 183.05$ for $2,4,5-\mathrm{T}$ dicamba, root plowing, and tame pasture establishment, respectively.

Average rainfall conditions (normal variation within a 20-year period) and sound grazing management following treatment were assumed for development of the response curves. Deferment costs were included for treatments as needed. It was also assumed that honey mesquite control would not adversely affect wildlife habitat or hunting revenues. Each control alternative was evaluated as a separate activity within a ranch firm, and no indirect economic benefits were included in the analysis.

Variable costs for cow-calf production were developed from Texas Agricultural Extension Service Budgets (1978). Increases in annual variable livestock costs associated with adding a cow to an existing ranch firm averaged $\$ 74$ and ranged from $\$ 63$ to $\$ 82$ / cow, depending upon the particular resource region. Added annual livestock expenditures averaged $\$ 110 /$ cow and ranged from $\$ 94$ to $\$ 130 /$ cow for tame pasture alternatives across the State. These increased livestock costs were considered to be "out-of-pocket" costs and did not include fixed costs such as for land. ${ }^{3}$

${ }^{2} \mathrm{~A}$ critical assumption of this analysis is that essentially pure stands of honey mesquite were treated. Responses to alternatives evaluated could vary considerably if a pplied to mixed brush rather than single species stands. Tame pasture establishment, primarily to Kleingrass (Panicum coloratum L.), was considered fcasible only on range sites with deep soils and relatively high production potential. Tame pastures were assumed to be fertilized annually and intensively managed.

"Interest charges are not directly included in annual livestock costs. Interest charges are properly accounted in the analysis when the annual stream of net cash flows are converted to an accumulated net present value. 
Pretreatment beef production for the State was estimated to average $190 \mathrm{~kg} /$ weaned calf (average of steers and heifers with an $82 \%$ weaned calf crop). Livestock production increases following honey mesquite control were estimated to increase weaning weights by 4.5 to $11.3 \mathrm{~kg} /$ weaned calf after herbicide use, and by 4.5 to $22.7 \mathrm{~kg} /$ calf following mechanical brush control. Estimated calf crops were generally increased by $3 \%$ to $5 \%$ following honey mesquite control, but Soil Conservation Service estimates ranged from $2 \%$ to $10 \%$ depending upon the particular resource situation and treatment alternative (Whitson and Scifres 1980).

More detailed economic comparisons of honey mesquite control on the Rolling Plains and Rolling Red Plains were conducted because of the importance of range livestock production to the regional economies, and because honey mesquite is the primary range brush management problem in those regions. In addition to the honey mesquite control alternatives evaluated on a statewide basis, aerial applications of 2,4,5-T + dicamba (1:1) and 2,4,5-T+ picloram (4-amino-3,5,6-trichloropicolinic acid) (1:1), chaining one-way, and tree dozing (power grubbing) and seeding to native forage mixtures were also evaluated. Herbicides were assumed to be applied in standard carrier volumes ( 28.1 to 46.8 liters/ ha spray solution).

Partial budgeting was used to estimate changes in annual net cash flows over the 20-year planning period. Net cash flows (expressed in 1978 dollars) were obtained by subtracting annual increased costs from annual increased benefits. These net changes were calculated only for the treated area and did not include possible interactions of the treated areas with adjacent management units. Weaned calf prices, averaged for steers and heifers, were varied from $\$ 0.82 / \mathrm{kg}(\$ 37.00 / \mathrm{cwt})$ to $\$ 1.05 / \mathrm{kg}(\$ 47.50 / \mathrm{cwt})$. Salvage values were included in the last year of the planning horizon as a positive cash flow. Net cash flows were not adjusted for income taxes because of the widely differing impact that taxes could have for individual ranch operators.

Annual net cash flows were converted to a present value by multiplying each by the appropriate annual discount factor. ${ }^{4}$ The stream of annual present values were summed over the 20 -year planning period, and a honey mesquite control alternative was assumed to be economically feasible if the accumulated net present value was zero or positive for the given discount rate. Internal rates

${ }^{4} \mathrm{An}$ annual discount factor is defined as $(1+r)^{-n}$, where $r=$ annual interest (discount) rate and $n=$ number of years since implementation of the practice. of return were estimated by a computerized procedure which identified the specific discount rate resulting in a 20 -year accumulated net present value of zero.

\section{Results and Discussion}

\section{Statewide Analysis}

Aerial application of herbicide produced higher annual rates of return on the investment than did mechanical treatments, regardless of resource region (Table 1). Annual rates of return from 2,4,5-T applied to dense canopies on deep range sites varied from $7.0 \%$ in the Trans Pecos to $21.8 \%$ on the Rio Grande Plains. Annual rates of return also varied with site potential within resource region. For example, weighted (by acres of dense canopy) rates of return from aerial applications of $2,4,5-\%$ were $15.7 \%$ from deep range sites and $11.1 \%$ from shallow sites. Variation in annual rates of return from deep range sites was less than annual rates of return from shallow range sites. Highest rates of return from herbicides occurred when $2,4,5-\mathrm{T}$ was aerially applied to honey mesquite stands on deep range sites of the Rio Grande Plains, and lowest returns occurred when dicamba was applied to shallow sites of the Trans Pecos.

Average rates of return from dicamba were almost one-third lcss than annual rates of return from 2,4,5-T (Table 1). Differences in rates of return from $2,4,5-\mathrm{T}$ and dicamba were attributable to differences in treatment costs since control responses were assumed to be the same (Scifres 1973; Scifres and Hoffman 1972).

Weighted average annual rates of return from the selected mechanical alternatives on deep range sites were substantially lower than from aerial herbicide application (Table 1). Rates of return averaged $3.9 \%$ (ranged from $0.9 \%$ to $5.2 \%$ ) from root plowing and seeding rangeland with a native forage mixture, and $5.1 \%$ (ranged from $1.9 \%$ to $6.9 \%$ ) for tame pasture establishment. Annual rates of return on shallow range sites from root plowing and seeding a native grass mixture were $2.4 \%$ or less, and were negative for three of the five vegetation resource regions evaluated.

\section{Rolling Plains and Rolling Red Plains}

Projected pretreatment annual weaned calf production ranged from about $10 \mathrm{~kg} /$ ha to $14 \mathrm{~kg}$ / ha from rangelands of the Rolling Plains which supported a dense canopy cover of honey mesquite (Table 2). Annual potential livestock production increases from deep sites on the Rolling Red Plains ranged from $7.6 \mathrm{~kg} / \mathrm{ha}$ follow-

Table 1. Representative annual rates of return (\%) from selected honey mesquite control alternatives by range site (deep, shallow), based on a cow-calf operation, dense mesquite canopy covers, and \$0.97/ $\mathbf{k g}$ cattle prices (1978 dollars) using a 20-year planning horizon, Texas. ${ }^{1}$

\begin{tabular}{|c|c|c|c|c|c|c|c|}
\hline \multirow[b]{3}{*}{ Resource region } & \multicolumn{7}{|c|}{ Treatment } \\
\hline & \multicolumn{2}{|c|}{$2,4,5-\mathrm{T}$} & \multicolumn{2}{|c|}{ Dicamba } & \multicolumn{2}{|c|}{ Rootplowing-seeding } & \multirow{2}{*}{$\frac{\text { Tame pastures }^{3}}{\text { Deep }}$} \\
\hline & Deep & Shallow & Deep & Shallow & Deep & Shallow & \\
\hline High Plains & 9.5 & - & 5.5 & - & 2.9 & - & - \\
\hline Rolling Plains & 14.6 & 7.9 & 10.5 & 3.5 & 3.9 & 1.9 & 5.7 \\
\hline Rolling Red Plains & 15.4 & 11.1 & 10.8 & 7.6 & 3.3 & -0.2 & 4.5 \\
\hline Cross Timbers & 12.3 & - & 8.2 & - & 4.7 & - & 2.6 \\
\hline North Central Prairies & 19.5 & 18.1 & 13.6 & 11.7 & 2.8 & -1.0 & 6.5 \\
\hline Grand Prairies & 11.1 & 3.5 & 6.1 & 1.7 & 0.9 & -0.1 & 4.1 \\
\hline Blackland Prairies & 13.5 & 11.7 & 9.5 & 7.7 & 4.6 & - & 3.1 \\
\hline Texas Claypan & 14.0 & 11.4 & 11.5 & 7.7 & 2.3 & - & 1.9 \\
\hline East Texas & 13.1 & - & 8.2 & - & - & - & 4.6 \\
\hline Coastal Prairies & - & - & - & - & 1.1 & - & 2.2 \\
\hline Rio Grande Plains & 21.8 & - & 16.6 & - & 5.2 & - & 3.7 \\
\hline Edwards Plateau & 15.2 & 13.5 & 11.0 & 9.7 & 4.6 & 2.4 & 6.9 \\
\hline Central Basin & 14.1 & - & 9.9 & - & 2.7 & - & - \\
\hline Trans-Pecos & 7.0 & -4.4 & 3.3 & -8.3 & 2.4 & - & - \\
\hline Weighted Aug. & 15.7 & 11.1 & 11.2 & 6.9 & 3.9 & 1.6 & 5.1 \\
\hline
\end{tabular}

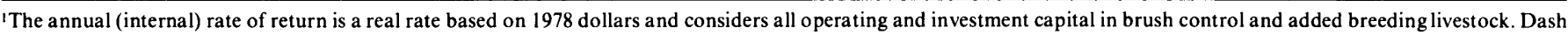
indicates alternative not evaluated for that resource region/range site situation.

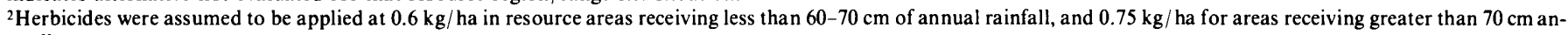
nually.

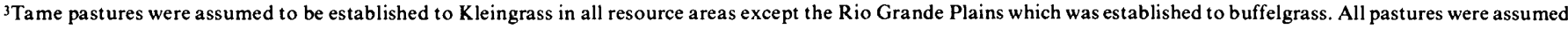
to be intensively managed, and received annual application(s) of fertilizer.

${ }^{4}$ Weighted by acres of dense canopy estimated for each resource region from Whitson and Scifres (1980). 
Table 2. Average annual beef production potential (kg/ha) following control of dense canopy covers of honey mesquite based on cow-calf operations on the Rolling Plains and Rolling Red Plains of Texas, 1978. ${ }^{1}$

\begin{tabular}{|c|c|c|c|c|}
\hline \multirow[b]{2}{*}{ Initial control alternative ${ }^{2}$} & \multicolumn{2}{|c|}{ Rolling Plains } & \multicolumn{2}{|c|}{ Rolling Red Plains } \\
\hline & Deep soils & Shallow soils & Deep soils & Shallow soils \\
\hline Pretreatment & 13.9 & 11.7 & 12.6 & 9.6 \\
\hline $2,4,5-\mathrm{T}$ & 21.1 & 15.7 & 20.2 & 15.0 \\
\hline Dicamba & 21.1 & 15.7 & 20.2 & 15.0 \\
\hline $2,4,5-T+$ dicamba $(1: 1)$ & 21.1 & 15.7 & 20.2 & 15.0 \\
\hline $2,4,5-\mathrm{T}+$ picloram $(1: 1)$ & 22.4 & 16.6 & 20.8 & 15.7 \\
\hline Chain & 21.0 & - & 10.7 & - \\
\hline Treedoze-seed & 24.0 & 20.8 & 26.8 & 16.4 \\
\hline Rootplow-seed & 27.3 & 21.3 & 29.8 & 18.8 \\
\hline Tame pasture ${ }^{3}$ & 48.3 & - & 61.9 & - \\
\hline
\end{tabular}

'Production responses adapted from Whitson and Scifres (1979) and averaged over a 20-year planning period. Dashes indicated practice not evaluated.

${ }^{2}$ Herbicides aerially applied initially and as maintenance treatments at $0.6 \mathrm{~kg} / \mathrm{ha}$. Initial mechanical treatments were generally followed by low-energy grubbing (Wiedemann et al. 1977) except for chaining which was followed by aerial application of 2,4.5-T.

${ }^{3}$ Tame pastures were seeded to Kleingrass and were intensively managed thereafter with annual fertilizer applications of $56-112 \mathrm{~kg} \mathrm{~N} / \mathrm{ha}$.

ing aerial application of herbicides to $49.3 \mathrm{~kg} /$ ha from establishment of tame pastures. This compared to beef production increases of $7.2 \mathrm{~kg} / \mathrm{ha}$ and $34.4 \mathrm{~kg} / \mathrm{ha}$, respectively, when the same alternatives were selected for the Rolling Plains. Robison et al. (1970) reported average weaning weight increases equivalent to $1.8 \mathrm{~kg} / \mathrm{ha}$ without adjusting stocking rates. Cross and Fisher (1970) reported average increases of $4 \mathrm{~kg} / \mathrm{ha}$ with only a moderate increase in stocking rate following aerial spraying, and with initial beef production levels $(20 \mathrm{~kg} / \mathrm{ha}$ to $21.5 \mathrm{~kg} / \mathrm{ha})$ which were much higher than pretreatment average beef production levels in this study. Projected beef production increases from shallow range sites in the Rolling Plains varied from $4.0 \mathrm{~kg} /$ ha to $9.6 \mathrm{~kg} / \mathrm{ha}$, depending on the alternative selected, compared to increases of $5.4 \mathrm{~kg}$ / ha to 9.2 $\mathrm{kg} /$ ha for comparable situations on the Rolling Red Plains (Table 2).

\section{Annual Rates of Return}

Highest annual rates of return from honey mesquite control on the Rolling Plains resulted from aerial applications of 2,4,5-T (0.6 $\mathrm{kg} / \mathrm{ha}$ ) on deep range sites (Table 3), and ranged from $9.6 \%$ to $16.9 \%$ for cattle prices of $\$ 0.816 / \mathrm{kg}(\$ 37.00 / \mathrm{cwt})$ and $\$ 1.047 / \mathrm{kg}$ $(\$ 47.50 / \mathrm{cwt})$, respectively. Chaining one-way followed by aerial application of 2,4,5-T produced annual rates of return comparable to those from aerial applications of dicamba or 2,4,5-T + picloram (1:1) at $0.6 \mathrm{~kg} / \mathrm{ha}$. Tree dozing or root plowing followed by seeding with a native forage mixture represented rather limited economic opportunities unless cattle prices averaged greater than $\$ 1.047 / \mathrm{kg}$, and unless only the more productive range sites were selected for honey mesquite control.

Annual rates of return on the investment in honey mesquite control were relatively low from shallow range sites, and would not likely meet minimal ranch firm economic criteria unless cattle prices averaged $\$ 1.047 / \mathrm{kg}$ or higher, and / or $2,4,5-\mathrm{T}$ or $2,4,5-\mathrm{T}+$ dicamba were selected as the control alternative. Mechanical alternatives produced relatively low annual rates of return, and would likely be rejected by management for application to shallow range sites.

\section{Cash Flows}

Net cash flows resulting from honey mesquite control (Table 4) represent the maximum yearly interest payment $(\$ /$ ha) the ranch manager could make (on the average) and still recover all added investment in the alternative. The magnitude of investment and timing of the net cash flows are important considerations when determining economic feasibility of a given practice. Thus, two alternatives with similar average net cash flows could generate different annual rates of return. Since similar livestock production responses over time were projected from the herbicide treatments, differences in rates of return can be attributed to differences investment costs.

The maximum interest rates that the manager could pay and break even are represented by the projected annual rates of return (Table 3). If the opportunity cost of owned capital or the cost of borrowing was less than the annual rates of return, the investment in honey mesquite control would be considered economically feasible.

Table 3. Annual rates of return (\%) from control of dense canopy covers of honey mesquite based on cow/calf operations over a 20 -year planning horizon and two livestock price (\$/kg) situations on the Rolling Plains and Rolling Red Plains of Texas. ${ }^{1}$

\begin{tabular}{|c|c|c|c|c|c|c|c|c|}
\hline \multirow[b]{4}{*}{ Initial control alternatives ${ }^{2}$} & \multicolumn{4}{|c|}{ Rolling Plains } & \multicolumn{4}{|c|}{ Rolling Red Plains } \\
\hline & \multicolumn{2}{|c|}{ Deep soils } & \multicolumn{2}{|c|}{ Shallow soils } & \multicolumn{2}{|c|}{ Deep soils } & \multicolumn{2}{|c|}{ Shallow soils } \\
\hline & \multicolumn{4}{|c|}{ Livestock price $(\$ / \mathrm{kg})$} & \multicolumn{4}{|c|}{ Livestock price (\$/kg) } \\
\hline & 0.816 & 1.047 & 0.816 & 1.047 & 0.816 & 1.047 & 0.816 & 1.047 \\
\hline $2,4,5-\mathrm{T}$ & 9.6 & 16.9 & 3.9 & 9.9 & 10.2 & 17.9 & 7.1 & 13.0 \\
\hline Dicamba & 6.1 & 12.5 & -0.1 & 5.2 & 6.1 & 13.0 & 4.3 & 9.3 \\
\hline $2,4,5-T+$ dicamba $(1: 1)$ & 8.8 & 15.9 & 2.8 & 8.6 & 9.2 & 16.7 & 6.4 & 12.0 \\
\hline $2,4,5-\mathrm{T}+$ picloram $(1: 1)$ & 4.8 & 11.2 & 0.6 & 6.1 & 6.0 & 12.0 & 3.3 & 8.5 \\
\hline Chain & 7.1 & 12.5 & - & - & 6.6 & 12.3 & - & - \\
\hline Treedoze-seed & 0.7 & 2.8 & 0.5 & 2.7 & 3.1 & 5.8 & -1.5 & 0.1 \\
\hline Rootplow-seed & 2.1 & 5.1 & 0.5 & 2.6 & 1.8 & 4.0 & -1.2 & 0.3 \\
\hline Tame pastures ${ }^{3}$ & 2.9 & 7.1 & - & - & 1.4 & 6.0 & - & - \\
\hline
\end{tabular}

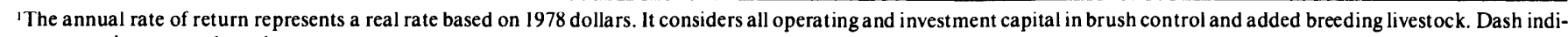
cates practice not evaluated.

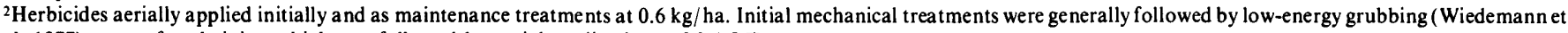
al. 1977) except for chaining which was followed by aerial applications of $2,4,5-\mathrm{T}$.

${ }^{3}$ Tame pastures were seeded to Kleingrass and were intensively managed thereafter with annual fertilizer applications of 56 to $112 \mathrm{~kg} \mathbf{N} /$ ha. 
While annual net cash flow is a useful consideration in the financial planning of honey mesquite control investments, it should not be used as the economic criterion for selecting the "best" practice from among mutually exclusive alternatives. The timing of cash flows and the magnitude of the investment are important functions in determining rates of return, and must be properly considered when selecting honey mesquite control alternatives. For example, tree dozing and seeding to a native range mixture produced about the same net cash flow $(\$ /$ ha $)$ as did aerial application of dicamba for honey mesquite control. However, positive cash flow increases occurred later in the 20 -year period following tree dozing than from aerial applications of dicamba. Furthermore, initial costs of tree dozing could require 5 to 10 times more investment capital than use of the herbicide. Consequently, the annual rate of return from dicamba was $12.5 \%$, compared to $2.8 \%$ from tree dozing and seeding (Table 3 ).

\section{Selection of the "Best" Practice}

As with most investments, ranch managers are faced with the problem of selecting the "best" honey mesquite control practice from among several alternatives. Obviously, the concept of "best" practice may vary among ranch managers because of personal preferences and characteristics unique to the operation of any particular firm. The "best" specific honey mesquite control practice, chosen from among mutually exclusive alternatives, is decided by considering factors such as capital availability, opportunity costs, objectives of management, risk and uncertainty differences among treatments, and potential synergisms or complementary effects of a given treatment with the remaining untreated management units on the ranch.

Annual rates of return provide a basis to eliminate alternatives that do not meet minimum rates of return. However, the proper use of an annual rate of return as the means to select the "best" practice from mutually exclusive alternatives requires an "incremental basis" approach which was not undertaken for this study (Haley and Schall 1973). Another accepted approach is to select the practice which produces the greatest accumulated present value for a given discount rate (differences in risk levels between treatments could be considered by adjustment in the discount rate ${ }^{5}$. This method assumes that adequate capital is available to carry out all alternatives.

Given an annual interest rate of $0 \%$ (a dollar is assumed to be as valuable to a manager at some point in the future as a dollar received today), tame pastures represented the "best"alternative to

\footnotetext{
SThere was no attempt to adjust for risk and uncertainty associated with the improvements methods evaluated in this study. Decision makers utilizing these results may select different discount rates in order to account for risk differences between
} treatments.
Table 5. Twenty-year value (\$/ha, 1978 dollars) of control of dense canopy covers of honey mesquite on deep soils for a cow-calf operations based on a $\$ 1.047 / \mathbf{k g}$ cattle price on the Rolling Plains of Texas. ${ }^{1}$

\begin{tabular}{lrrrr}
\hline \hline & \multicolumn{4}{c}{ Present value $(\$ /$ ha $)$} \\
\cline { 2 - 5 } & \multicolumn{4}{c}{ Annual interest rate (\%) } \\
\cline { 2 - 5 } Initial control alternative ${ }^{2}$ & \multicolumn{1}{c}{5} & \multicolumn{1}{c}{5} & 7 & \multicolumn{1}{c}{9} \\
\hline $2,4,5-T$ & 69.70 & 31.28 & 22.27 & 15.36 \\
Dicamba & 61.28 & 23.38 & 14.64 & 8.05 \\
$2,4,5-T+$ dicamba (1:1) & 67.06 & 30.12 & 21.11 & 14.12 \\
$2,4,5-T+$ picloram (1:1) & 67.01 & 24.00 & 14.00 & 6.40 \\
Chain & 75.21 & 30.86 & 19.75 & 10.99 \\
Treedoze-seed & 63.43 & -30.49 & -50.86 & -65.75 \\
Rootplow-seed & 103.51 & 0.35 & -23.75 & -42.02 \\
Tame pasture & 261.04 & 48.77 & 1.88 & -32.64 \\
\hline
\end{tabular}

'Accumulated net present values were determined by estimating annual cash flows, converting each annual cash flow to a present valuc and summing over time

${ }^{2}$ Herbicides aerially applied initially and as needed for maintenance at $0.6 \mathrm{~kg} / \mathrm{ha}$. Initial mechanical treatments were generally followed by low-energy grubbing (Wiedemann et al. 1977) except for chaining which was followed by aerially applied 2,4,5-T.

${ }^{3}$ Tame pastures were seeded to Kleingrass and were intensively managed thereafter with annual fertilizer applications of $56-112 \mathrm{~kg} \mathrm{~N} / \mathrm{ha}$

increase returns to the ranch (Table 5). The next "best" alternative would be root plowing and seeding to a native forage mixture, followed by chaining and finally by aerial application of herbicides. If the ranch manager required at least a $5 \%$ annual rate of return on his investment, tame pastures again produced the greatest present value but the "next best" alternative shifted to aerial application of $2,4,5-\mathrm{T}$. Thus, while establishment of tame pasture generated the sixth lowest annual rate of return (Table 3), it produced the greatest total present value when the rancher's economic criterion was a $5 \%$ annual rate of return or lower (Table 5). That is, all added investment inputs required to establish the tame pasture yielded a $5 \%$ annual return and produced an additional $\$ 48.77 /$ ha accumulated net present value. Thus, the rancher would have been $\$ 48.77 /$ ha "better off" to invest in establishment of tame pastures than from making an equivalent investment in a savings account paying a real annual rate of $5 \%$ over a 20 -year planning horizon.

When a $7 \%$ annual rate of return was the investment criterion, the "best" practice was aerial application of 2,4,5-T (Table 5). Using a $9 \%$ investment criterion, only chaining and aerial application of herbicides were economically feasible (net present value must be greater than zero for alternative to be considered as feasible).

Table 4. Increased annual net cash flows $(\$ / \mathrm{ha})$ from control of dense canopy cover of honey mesquite based on cow-calf operations over a 20 -year planning horizon and two livestock price $(\mathbf{S} / \mathbf{k g})$ situations on the Rolling Plains and Rolling Red Plains of Texas. ${ }^{\mathrm{I}}$

\begin{tabular}{|c|c|c|c|c|c|c|c|c|}
\hline \multirow[b]{4}{*}{ Initial control alternative ${ }^{2}$} & \multicolumn{4}{|c|}{ Rolling Plains } & \multicolumn{4}{|c|}{ Rolling Red Plains } \\
\hline & \multicolumn{2}{|c|}{ Deep soils } & \multicolumn{2}{|c|}{ Shallow soils } & \multicolumn{2}{|c|}{ Deep soils } & \multicolumn{2}{|c|}{ Shallow soils } \\
\hline & \multicolumn{4}{|c|}{ Livestock price (\$/kg) } & \multicolumn{4}{|c|}{ Livestock price $(\$ / \mathbf{k g})$} \\
\hline & 0.816 & 1.047 & 0.816 & 1.047 & 0.816 & 1.047 & 0.816 & 1.047 \\
\hline $2,4,5-T$ & 1.83 & 3.48 & 0.57 & 1.48 & 2.10 & 3.85 & 1.46 & 2.69 \\
\hline Dicamba & 1.41 & 3.06 & -0.02 & 0.91 & 1.43 & 3.21 & 1.06 & 2.30 \\
\hline $2,4,5-T+$ dicamba $(1: 1)$ & 1.68 & 3.36 & 0.42 & 1.33 & 1.95 & 3.70 & 1.36 & 2.59 \\
\hline $2,4,5-\mathrm{T}+$ picloram $(1: 1)$ & 1.36 & 3.36 & 0.12 & 1.26 & 1.80 & 3.70 & 0.86 & 2.27 \\
\hline Chain & 2.07 & 3.78 & - & - & 1.95 & 3.83 & - & - \\
\hline Treedoze-seed & 0.84 & 3.19 & 0.52 & 2.64 & 3.33 & 6.62 & -1.38 & 0.20 \\
\hline Rootplow-seed & 2.07 & 5.19 & 0.52 & 2.77 & 2.91 & 6.91 & -1.65 & 0.49 \\
\hline Tame pastures $^{3}$ & 5.04 & 13.04 & - & - & 3.14 & 14.52 & - & - \\
\hline
\end{tabular}

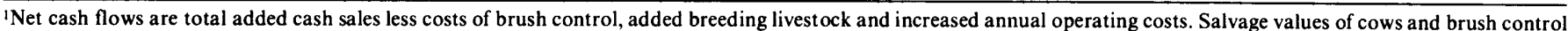

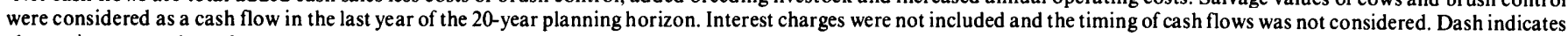
alternative not evaluated.

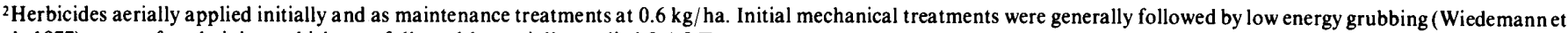
al. 1977) except for chaining, which was followed by aerially applied $2,4,5-\mathrm{T}$.

${ }^{3}$ Tame pastures were seeded to Kleingrass and were intensively managed thereafter with annual fertilizer applications of $56-112 \mathrm{~kg} N /$ ha. 


\section{Conclusions}

Economic responses to honey mesquite control varied considerably within and among vegetation resource areas of Texas. Annual rates of return for honey mesquite control depend upon range site production potential, degree of mesquite infestation, total investment required, projected livestock responses, livestock prices, and annual variable costs of production.

In general, aerial application of herbicides for control of dense canopy covers of honey mesquite on deep soils will likely represent an economically feasible investment for most producers. These results provide some insight regarding the popularity of aerial application of 2,4,5-T for honey mesquite control in Texas. Based on cconomic results from honey mesquite control on shallow range sites, aerial application of herbicides represents the principal feasible alternative, if any exist, for sites of relatively low production potential. Mechanical honey mesquite control, even on deep soils of relatively high production potential, generally offer limitcd investment opportunities to improve ranch firm profitability (based on annual rates of return) unless livestock prices average significantly greater than $\$ 0.97 / \mathrm{kg}$ over the 20 -year planning horizon, and/or treatment costs are reduced by new technology or cost-sharing arrangements. Profitability of mechanical treatments is especially limited when investment funds must be borrowed and additional charges for risk and uncertainty are included in the analysis.

Although intensively managed tame pasture alternatives appear to offer better rate of return possibilities than other mechanical practices evaluated, they usually require considerable investment capital. Additionally, rising costs of energy and fertilizer may reduce the projected rates of return for tame pasturc cstablishment.

It is emphasized that comparisons herein do not consider potential synergisms among alternatives - the possibility of selecting an appropriate mix of alternatives such that the annual rates of return to the firm would exceed rates of return from any one individual treatment. However, individual comparisons suggest that ranch managers must be highly selective in choosing honey mesquite control practices if economic considerations are important.

Dicamba was assumed to be the primary herbicide replacement should 2,4,5-T eliminated as a control alternative for honey mesquite. Projected annual rates of return from dicamba averaged about one-third less than potential rates of return from aerial application of 2,4,5-T. However, rates of return from aerial application of dicamba were generally higher than could be achieved from other honey mesquite control alternatives except aerial application of 2,4,5-T.

The identification of a "best" honey mesquite control practice, based solely on economic responses, may vary considerably among individuals depending on their investment criteria. Results for the Rolling Plains indicated that for a $5 \%$ or lower discount rate, an individual could economically justify establishing tame pasture instead of aerially applying a herbicide for honey mesquite control. For higher discount rates, the best economic choice was aerial application of herbicides, and 2,4,5-T was economically superior to the other herbicide alternatives.

This study did not consider price changes via shifts in beef supply or demand, the impact of the cattle price cycle, or the influence of federal cost sharing on economic results. Results would be less favorable if declining beef prices occurred during early years of the planning horizon. Also, effects of income taxes were not considered in this study. Although tax effects could have a significant impact on rates of return, cash flows, and total present value generated by honey mesquite control, the number of possible tax scenerios were so great as to be beyond the scope of this study. Finally, this study did not consider the influence of firm size, particularly inherent requirements for minimal cash flows or availability of investment capital, on alternative selection. However, the relative importance of all these variables influence selection of alternatives for honey mesquite control should be considered in future studies.

\section{Literature Cited}

Bovey, R.W., and R.E. Meyer. 1974. Mortality of honey mesquite and huisache seedlings from herbicides and top removal. Weed Sci. 22:276279

Boykin, C.C., Jr. 1960. Costs of root plowing and seeding rangeland, Rio Grande Plain. Texas Agr. Exp. Sta. MP-425. 8 p.

Brown, T.C., P.R. O'Connell, and A.R. Hibbert. 1974. Chaparral conversion potential in Arizona Part II: An economic analysis. U.S. Dep. Agr. Forest Serv. Res. Pap. RM-127. 28 p.

Cross, B.T., and C.E. Fisher. 1975. Influence of aerial spraying honey mesquite on the weight of weaner calves and lambs. Texas Agr. Exp. Sta. Cons. Prog. Rep. 3341:12-13.

Dahl, B.E., R.E. Sosebee, J.P. Goen, and C.S. Brumley. 1978. Will mesquite control with 2,4,5-T enhance grass production? J. Range Manage. $31: 129-131$

Fisher, C.E., C.H. Meadors, R. Behrens, E.D. Robison, P.T. Marion, and H.I. Morton. 1959. Control of mesquite on grazing lands. Tex. Agr. Exp. Sta. Bull. 935

Fisher, C.E., E.D. Robison, G.O. Hoffman, C.H. Meadors, and B.T. Cross. 1970. Aerial applications of chemicals for control of brush on rangelands. Tex. Agr. Exp. Sta. Prog. Rep. 2801. p. 5-11. In: Brush Research in Texas-1970. Tex. Agr. Exp. Sta. Consol. PR-2801-2828. 102 p.

Haley, C.W., and L.D. Schall. 1973. The Theory of Financial Decisions. p. 43-72. McGraw-Hill, Inc., New York. 383 p.

Osborn, J.E., and G.V. Witkowski. 1974. Economic impact of brush encroachment in Texas. So. J. Agr. Econ. 6:95-100.

Rohison, E.D., B.T. Cross, P.T. Marion, and S.P. Hammack. 1969. Beef and forage production following mesquite control. Tex. A\&M Res. Sta. Spur, Texas. Tech. Rep. No. 8.

Robison, E.D., B.T. Cross, and C.E. Fisher. 1970. Effect of aerial honey mesquite control on beef and forage production. Tex. Agr. Exp. Sta. Prog. Rep. 2802, p. 11-15. In: Brush research in Texas-1970. Tex. Agr. Exp. Sta. Consol. PR-2801-2828. 102 p.

Scifres, C.J. 1980. Brush Management. Principles and Practices for Texas and the Southwest. Texas A\&M Univ. Press, College Sta. 360 p.

Scifres, C.J. (Ed.). 1973. Mesquite. Tex. Agr. Sta. Res. Monogr. 1:84 p.

Scifres, C.J., and G.O. Hoffman. 1972. Comparative susceptibility of honey mesquite to 2,4,5-T and dicamba. J. Range Manage. 25:143-145.

Scifres, C.J., G.P. Durham, J.L. Mutz. 1977. Range forage production and consumption following aerial spraying of mixed brush. Weed Sci. 25:4854.

Sharp. W.W., and C.C. Boykin. 1967. A dynamic programming model for evaluating investments in mesquite control and alternative beef cattle systems. Tex. Agr. Exp. Sta. Tech. Monogr. 4. 38 p.

Smith, H.N., and C.A. Rechenthin. 1964. Grassland restoration. The Texas brush problem. U.S. Dep. Agr., Soil Conserv. Serv. Unnumbered Pub. $33 \mathrm{p}$.

Texas Agricultural Extension Service. 1978. Cow calf production (by region), estimated costs and returns per cow. Livestock budgets projected 1978-1979.

U.S. Dep. of Agriculture. 1970. Conservation needs inventory: Texas 1970. Soil Conserv. Serv. Tex. Cons. Needs Committee. 297 p.

Whitson, R.E., and C.J. Scifres. 1980. Economic comparison of alternatives for improving honey mesquite-infested rangeland. Texas Agr. Exp. Sta. Bull. 1307-C:

Whitson, R.E., W.T. Hamilton, and C.J. Scifres. 1979. Techniques and considerations for economic analysis of brush control alternatives. Tex. Agr. Exp. Sta., Dep. Range Sci. Tech. Rep. 29-1. 40 p. (mimeo).

Whitson, R.E., C.J. Scifres, and B.D. Polk, Jr. 1975. Economic efficiency of ashe juniper control in the Edwards Plateau. p. 59-60. In: Rangeland Resources Res. 1971-1974. Tex. Agr. Exp. Sta. PR-3341. 70 p.

Whitson, R.W., S.L. Beasom, and C.J. Scifres. 1977. Economic evaluation of cattle and whitetailed deer responses to aerial spraying of mixed brush. J. Range Manage. 30:214-217.

Wiedemann, H.T., and B.T. Cross. 1975. Low-energy grubbing for economcial control of small trees. p. 35-36. In: Rangeland Resources Res. 1971-74. Tex. Agr. Exp. Sta. PR-3341. 70 p.

Wiedemann, H.T., B.T. Cross, and C.E. Fisher. 1977. Low-energy grubber for controlling brush. Trans. Amer. Soc. Agr. Engr. 20:210-213.

Workman, D.R., C.R. Tefertiller, and C.L. Leinweber. 1965. Profitability of aerial spraying to control mesquite. Tex. Agr. Exp. Sta. MP-425. 8 p. 